\title{
EFFECTS OF SOME INSECTICIDES AND NEMATICIDES ON PENETRATION, INFECTIVITY AND REPRODUCTION OF THE ENTOMOPATHOGENIC NEMATODES
}

Anany, A. E. ; A. F. El-Mesalamy ${ }^{\star \star} ;$ A.A. Deabes ${ }^{\star \star \star}$ and A. M. Kella $a^{\star \star \star \star}$

* Agric. Zollogy and Nematoyogy Dept. Fac. of Agric., Al-Azhar Univ.

** Agric. Zollogy and Nematoyogy Dept. Faculty of Agriculture Al-Azhar University at Assiut

*** Central Laboratory of Pesticides. Plant protection Institute. Agricultural Research Centre

**** Nematoyogy Dept., Plant Diseases Inst., Agric. Research Centre

\begin{abstract}
Laboratory bioassays were conducted to determine the effects of seven insecticides and three nematicides on penetration , infectivity and reproduction of the infective juveniles (IJs)of entomopathogenic nematodes Heterorhabditis bacteriophora and $\mathrm{H}$. indica nematode species. In penetration assay, results of tested seven insecticides i.e. abamactin, Bacillus thuringiensis B.t. as bioinsecticides, chloropyrifos, chloropyrifos-methyl, esfenvalerate, methomyl and profenfos as chemical insecticides on both of entomopathogenic nematodes, indicate that the more pesticides events for reduction in average numbers of IJs nematodes penetrating last instar larvae of Spodoptera littoralis was chloropyrifos-methyl and methomyl at $100 \%$ reduction comparing with control. While the more pesticides compatible with tested nematode species are abamactin and B.t on the three tested rates of application. In infectivity and reproduction assays, three nematicides has been tested i.e. aldicarb, ethoprophos and cadusafos at three rates of application after four periods of exposure soil to tested nematicides at one day, one week, two weeks, three weeks. Results show that, the most compatible nematicides with $H$. bacteriophora are cadusafos in both assayes production and efficiency against Galleria mellonella larvae comparing with control, while other pesticides tested is not compatible with this nematode where the aldicarb at percentage $100 \%$ reduction in events insect larvae death, as well as test production by day, week, 2 weeks. Overall, results indicate the feasibility of an integrated use of these nematode species and chemical pesticides in crop protection.

Keywords: Entomopathogenic nematodes, insecticides, nematicides, penetration, infectivity, reproduction, Heterorhabditis bacteriophora, H.indica, Spodoptera littoralis.
\end{abstract}

\section{INTRODUCTION}

Entomopathogenic nematodes (EPNs) are considered as one of the most promising non-chemical control alternatives for insect pests. In developing integrated pest management (IPM) strategies involving the use of entomopathogenic nematodes (Fam. :Steinernematidae and Heterorhabditidae) and chemical pesticides, it is important to ascertain the degree to which these nematodes may be affected by the chemicals involved.

Many studies have addressed the consequences of direct exposure to solutions of insecticides on the behavior and infectivity of selected entomopathogenic nematode species (Hara and Kaya, 1982, 1983; Rovesti 
et al., 1988; Zhang et al., 1994; Gordon et al.,1996) and detrimental effects reducing infectivity and motility have been recorded for several compounds (Rovesti and Deseo, 1990; Gaugler and Campbell, 1991). However it has also been suggested that exposure to certain chemicals may stimulate nematode movement and enhance host finding behaviour and penetration of the host (Ishibashi and Takii, 1993).. Patel and Wright(1996) studied the exposure Steinernema carpocapsae Weiser and $S$. feltiae Filipjev to two neuroactive pesticides i.e. oxamyl and fenamiphos, widely used against plant parasitic nematodes, and found that oxamyl $\left(50 \mu \mathrm{g} \mathrm{ml}^{-1}\right)$ initially stimulated non-sinusoidal movement in $S$. feltiae but had no appreciable effect on IJs of $S$. carpocapsae, while fenamiphos (10 and $50 \mu \mathrm{g} \mathrm{ml}^{-1}$ ) increased and sustained non-sinusoidal movement in both species over an observation period of $48 \mathrm{~h}$. Moreover the two pesticides reduced the infectivity of both nematode species against late instar larvae of the wax moth, Galleria mellonella L. Elizabeth et al. (2003) found that $S$. feltiae is compatible with the majority of the tested formulations (17 different pesticides and three plant growth regulators) with no loss in viability and infectivity up to $24 \mathrm{~h}$ of exposure. Three pesticide formulations, Prostar (1\%), Gnatrol (9\%), and Terrazole $(10 \%)$ decreased the viability of $S$. feltiae significantly within $24 \mathrm{~h}$ compared to the control. However, during the 24 to $72 \mathrm{hr}$ incubation period, eight pesticides affected the viability of $S$. feltiae with Gnatrol and Terrazole causing the highest decrease (17\% and $15 \%$, respectively). Only Terrazole decreased the infectivity of S. feltiae to Galleria mellonella larvae compared to the control when tested after $24 \mathrm{~h}$ exposure. At $72 \mathrm{hr}$, Orthene and Terrazole caused significant decrease in the infectivity of $S$. feltiae $(10 \%$ and $15 \%$, respectively)

The present study was done to determine the effect of selected insecticides and nematicides on infectivity, penetration and reproduction of the entomopathogenic nematodes using Galleria mellonella and Spodoptera littoralis larvae as insect target.

\section{MATERIALS AND METHODS}

Nematdes. Nematodes were routinely cultured in greater wax moth Galleria mellonella L. (Woodring and Kaya , 1988) entomopathogenic nematodes, Heterorhabditis bacteriophora and $H$. indica were used in bioassays which collected at Behira Governorate (Anany,2005). Nematodes were stored at 15 ${ }^{\circ} \mathrm{C}$. as aqueous suspensions in tissue culture flasks $250 \mathrm{ml}$, no longer than one week before use in bioassay.

Insects. The cotton leaf worm, Spodoptera littoralis was used as a model to test the effect of insecticides on penetration of entomopathogenic nematodes. The culture of the cotton leaf worm was reared under laboratory conditions of $26^{\circ} \mathrm{C}$ and $65 \%$ R.H. The colony was reared for several generation befor using the larvae in the bioassay experiments. The egg mass were allowed to hatch in clean jars provided with leaves castor plants (Ricinus communis). The larvae continued their development till pupation. The pupae were collected in separate jars until adult emergence. Moths were fed on 10 sugar solution. 
The greater wax moth Galleria mellonella L. larvae were reared in the laboratory on artificial diet at a constant temperature of $27 \pm 1^{\circ} \mathrm{C}$ and $65 \pm 5 \%$ R.H .

Pesticides. All tested insecticides and nematicides were obtained from Central Laboratory of Pesticides, Plant Protection Institute - Agricultural Research Centre.

Penetration assay. Experiments were conducted in cylindrical plastic cups $(4.5 \mathrm{~cm}$ height $\times 2.5 \mathrm{~cm}$ diameter ) filled with sterilized sandy soil. The tested insecticides were added at three tested rates of application per feddan e.g. abamactin $1.8 \%(50,60$ and $80 \mathrm{ml} / \mathrm{f}$. ), B.t. Bacillus thuringiensis $2 \mathrm{X}(150$, 175 and $200 \mathrm{~g} / \mathrm{f}$.), chloropyrifos $48 \%$ (700, 850 and $1000 \mathrm{ml} / \mathrm{f}$.$) ,$ chloropyrifos-methyl 50\% (700, 850 and $1000 \mathrm{ml} / \mathrm{f}$.), esfenvalerate $5 \%(400$, 500 and $600 \mathrm{ml} / \mathrm{f}$.), methomyl $90 \%$ (150, 200 and $300 \mathrm{~g} / \mathrm{f}$.) and profenfos $72 \%(500,600$ and $750 \mathrm{ml} / \mathrm{f}$.).Also the insecticides pipette on to the dry soil so that final moisture was standardized at field capacity ( $60 \%$ humidity). Approximately $100 \mathrm{lJs}$ of both insect nematode species $\mathrm{H}$. bacteriophora or $H$. indica were applied to each cup. Three replicates per each treatment , were incubated at $25^{\circ} \mathrm{C}$. After $24 \mathrm{hrs}$. of nematode exposure to insecticides, one last instar larvae of Spodoptera littoralis was added to each cup. After 3 4 more days, cadavers were dissected and the number of penetrating nematode were counted.

Infectivity assay. Cylindrical plastic cups ( $7 \times 6 \mathrm{~cm}$ diameter ) filled with 50 gm sterilized sandy soil . Each used nematicide were added at three rates i.e. the half of recommended, the recommended and two fold. So, the rates of each aldicarb, ethoprophos and cadusafos were at $(0.034,0.017$ and 0.0085 $\mathrm{gm} / 1 \mathrm{~kg}$ soil), (0.08, 0.04 and $0.02 \mathrm{gm} / 1 \mathrm{~kg}$ soil) and $(0.048,0.024$ and 0 . $012 \mathrm{gm} / 1 \mathrm{~kg}$ soil), respectively. Each rate of a nematicide was solved in 60 $\mathrm{ml}$ of sterilized water and incorporated with $1 \mathrm{~kg}$ mixture of soil so that final moisture was standardized at field capacity ( $60 \%$ humidity). Three replicates per each treatment were incubated at $25^{\circ} \mathrm{C}$. After one day, one week, two weeks and three weeks of soil to nematicides, $200 \mathrm{IJs}$ of $H$. bacteriophora nematodes were applied to each cup. . After 24 hours of nematode exposure to insecticides, five last instar larvae of G.melonella was added to each cup. Insect mortality was determined four days after infection.

Reproduction assays. This experiment was carried out as described in the infectivity bioassay except the use of plastic cups $(4.5 \times 2.5 \mathrm{~cm})$ by using the nematode concentration $50 \mathrm{lJs} /$ G.melonella larva .The infect cadavers were removed from the sand, rinsed, transferred to water traps and inoculated at $25^{\circ} \mathrm{C}$. All emerging IJs from a single larva were recovered over a period of 10 days and stored in culture flasks $250 \mathrm{ml}$. The content of each flask (nematode suspension from individual cadavers) was mixed thoroughly. Eight samples of $10 \mu$ from each suspension were examined under a stereomicroscope and the total number of IJs nematode per cadaver was calculated (Susurluk, 2006).

Statistical analyses. Data were then analyzed according to Duncan's (1955). 


\section{RESULTS}

\section{1- Exposure effects of $H$. bacteriophora and H.indica to seven} insecticides on nematode penetration.

The results reveal that all tested insecticides at different rates of application were found to suppress penetration rate of IJs in both tested nematode species on the last instar larvae of Spodoptera littoralis. Meanwhile they, significantly reduced $(\mathrm{P}=0.05$ ) penetration of both entomopathogenic nematodes species as compared with the control. Data presented in Table (1) and Fig . (1) showed that, the highest percentage reduction of $H$. bacteriophora and H.indica penetration to insect host larvae was obtained by exposure to chloropyrifos-methyl and methomyl at all tested rates of application( $100 \%$ reduction), followed by exposure to chloropyrifos, profenfos and esfenvalerate, while the lowest percentage reduction of nematode penetration were observed by exposure IJs of $H$. bacteriophora to B.t. and abamactin against IJs of H.indica at averages(52.66, 46.66 and42.0 IJs/cadaver) and (38.33, 29.33 and20.33 IJs/cadaver) at three levels of application, respectively.

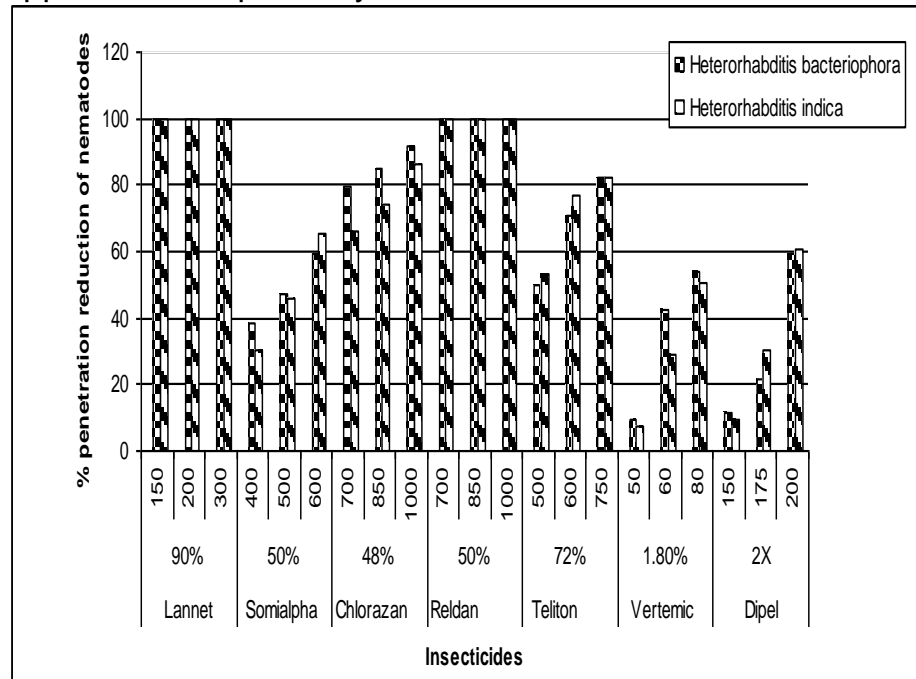
Fig. (1): Influence of seven insecticides on penetration of Heterorhabditis nematodes in last instar larvae of Spodoptera littoralis.

\section{2- The effect of three nematicides on infectivity of $\boldsymbol{H}$. bacteriophora against G. mellonella larvae.}

There was a significantly differences in the infectivity of IJs of $H$. bacteriophora after exposure to aldicarb or ethoprophos nematicides at one day, one week, two weeks or three weeks as exposure periods of the treated soil to tested nematicides when compared with the control . 
J. of Plant Protection and Pathology, Vol. 1 (4), April, 2010

T1

223 
Anany, A. E. et al.

Data indicate that $H$. bacteriophora did not kill larvae of $G$. mellonella when the nematicides aldicarb or ethoprophos were applied in soil at all tested exposure periods except that of ethoprophos after three weeks from application at 0.33 average mortality in G. mellonella larvae (Table 2 and Fig . 2).

\section{Aldicarb}

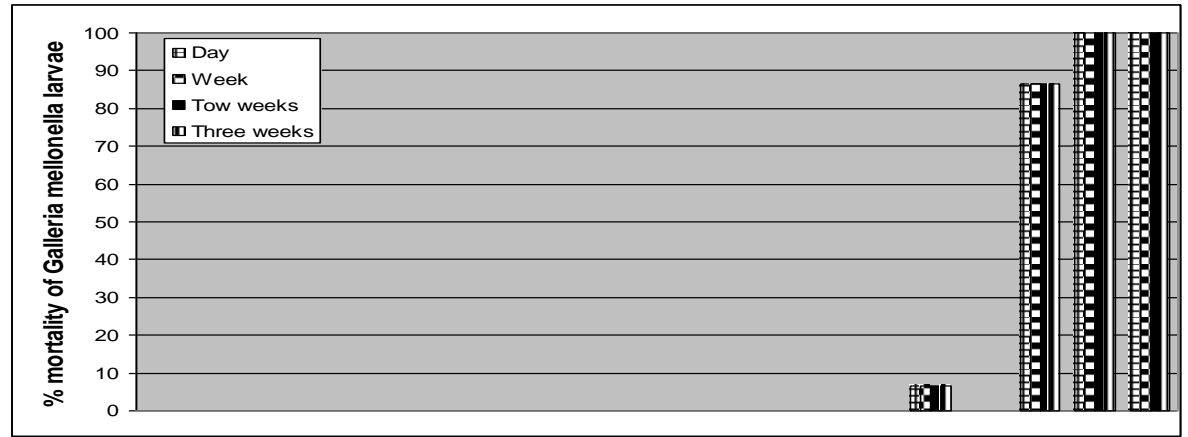

\section{Ethoprophos}

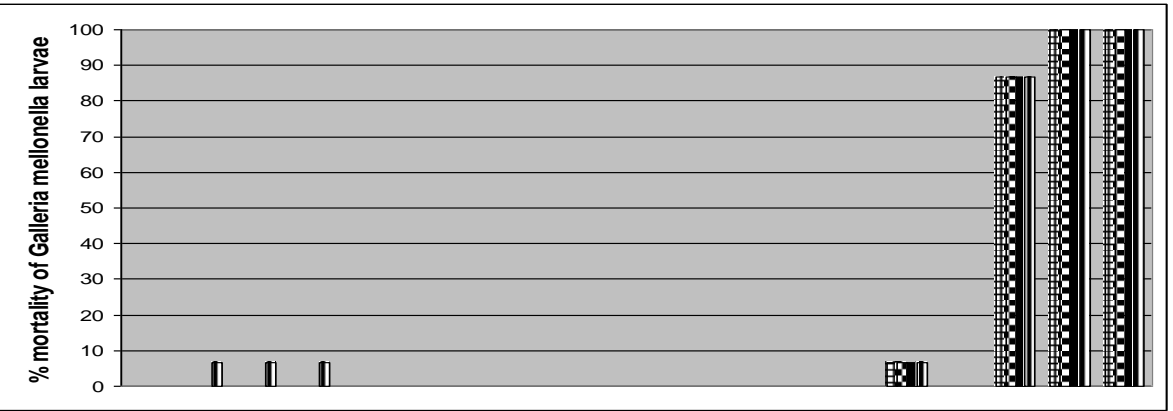

\section{Cadusafos}

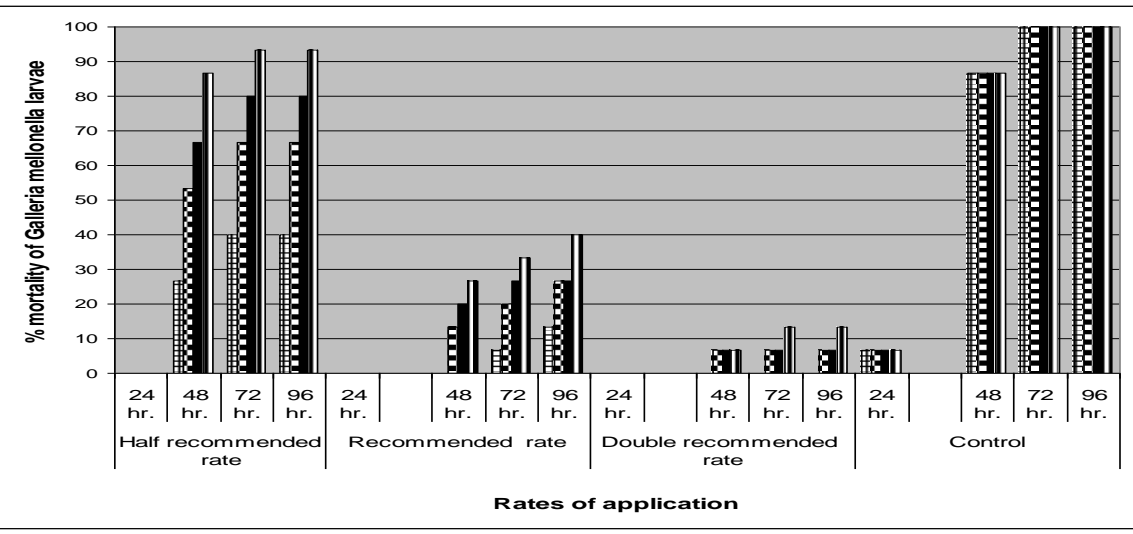

Fig.(2): Effect of three nematicides on mortality of G. mellonella larvae by IJs of $\boldsymbol{H}$. bacteriophora nematodes. 
J. of Plant Protection and Pathology, Vol. 1 (4), April, 2010

2 
Either after exposure the soil to cadusafos nematicide, the opening of mortality in G. mellonella caused after $48 \mathrm{hr}$. from exposure to nematodes all exposure periods. After one day, one week or two weeks as exposure periods the treated soil to cadusafos significantly different at all exposure times of insect larvae to $H$. bacteriophora nematodes at averages mortality in G. mellonella $(0.0,1.33,2.0$ and 2.0), $(0.0,2.66,3.33$ and 3.33) and (0.0, $3.33,4.0$ and 4.0$)$ at three exposure periods, respectively. Not significantly different after three weeks from application with cadusafos $(4.33,4.66$ and 4.66) at 48,72 and $96 \mathrm{hr}$. after exposure the insect larvae to nematodes , respectively.

3- Effect of three nematicides on reproduction of $\boldsymbol{H}$. bacteriophora in $\boldsymbol{G}$. mellonella larvae.

After exposure to aldicarb or ethoprophos nematicides at all tested levels of application significantly reduced ( $\mathrm{P}=0.05)$ reproduction of $H$. bacteriophora nematodes as compared with the control . Results in Table (3) and Fig . (3) indicate that $H$. bacteriophora did not develop and produce in larvae of G. mellonella when aldicarb or ethoprophos were applied in soil at all tested exposure periods and at all tested levels of application except after three weeks from application at half recommended level with averages 485300 and $188166 \mathrm{IJs} /$ cadaver, respectively. Whereas cadusafos nematicides significantly reduced nematode reproduction at all tested exposure periods and at all tested levels of application after three weeks except the half recommended level when compared with the control.

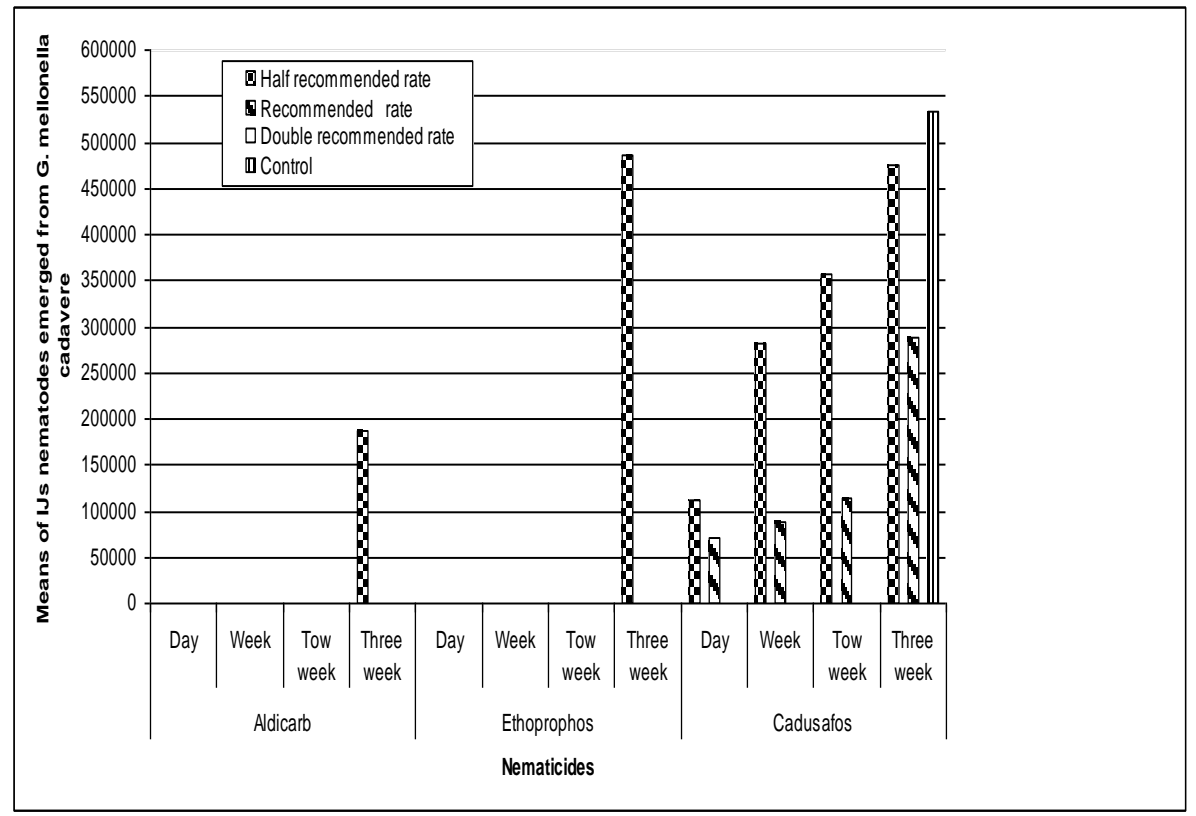

Fig.(3): Effect of three nematicides on reproduction of Heterorhabditis bacteriophora nematodes in Galleria mellonella cadavers. 
The highest percentage reduction in reproduction of nematodes was obtained at two fold, the recommended level (100\% reduction), followed by the recommended level(70333, 89183, 113000 and 289150 IJs/ cadaver) after the four tested exposure periods, respectively. But at half recommended level of application, the lowest percentage reduction in reproduction of nematodes was recorded after three weeks from exposure the treated soil to cadusafos.

Table (3): The influence of tested nematicides on reproduction of Heterorhabditis bacteriophora in Galleria mellonella larvae.

\begin{tabular}{|c|c|c|c|c|c|}
\hline \multirow[t]{2}{*}{ Nematicides } & \multirow[t]{2}{*}{$\begin{array}{c}\text { Rates of } \\
\text { application }\end{array}$} & \multicolumn{4}{|c|}{$\begin{array}{c}\text { * Means of IJs nematodes emerged from } G \text {. } \\
\text { mellonella cadavere }\end{array}$} \\
\hline & & Day & Week & Tow week & Three week \\
\hline \multirow[b]{3}{*}{ Aldicarb } & Half recommended rate & $0.0 \mathrm{~d}$ & $0.0 \mathrm{~d}$ & $0.0 \mathrm{~d}$ & $188166 \mathrm{~d}$ \\
\hline & Recommended rate & $0.0 \mathrm{~d}$ & $0.0 \mathrm{~d}$ & $0.0 \mathrm{~d}$ & $0.0 \mathrm{e}$ \\
\hline & Double recommended rate & $0.0 \mathrm{~d}$ & $0.0 \mathrm{~d}$ & $0.0 \mathrm{~d}$ & $0.0 \mathrm{e}$ \\
\hline \multirow[b]{3}{*}{ Ethoprophos } & Half recommended rate & $0.0 \mathrm{~d}$ & $0.0 \mathrm{~d}$ & $0.0 \mathrm{~d}$ & $485300 \mathrm{~b}$ \\
\hline & Recommended rate & $0.0 \mathrm{~d}$ & $0.0 \mathrm{~d}$ & $0.0 \mathrm{~d}$ & $0.0 \mathrm{e}$ \\
\hline & Double recommended rate & $0.0 \mathrm{~d}$ & $0.0 \mathrm{~d}$ & $0.0 \mathrm{~d}$ & $0.0 \mathrm{e}$ \\
\hline \multirow{3}{*}{ Cadusafos } & Half recommended rate & $112150 \mathrm{~b}(\mathrm{D})$ & $281666 \mathrm{~b}(\mathrm{C})$ & $357300 \mathrm{~b}(\mathrm{~B})$ & $474938 \mathrm{~b}(\mathrm{~A})$ \\
\hline & Recommended rate & $70333 \mathrm{c}(\mathrm{D})$ & $89183 c(C)$ & $113000 \mathrm{c}(\mathrm{B})$ & $289150 \mathrm{c}(\mathrm{A})$ \\
\hline & Double recommended rate & $0.0 \mathrm{~d}$ & $0.0 \mathrm{~d}$ & $0.0 \mathrm{~d}$ & $0.0 \mathrm{e}$ \\
\hline Control & & \multicolumn{4}{|c|}{$532500 \mathrm{a}$} \\
\hline
\end{tabular}

\section{DISCUSSION}

This study shows that the presence of tested insecticides and nematicides in soil adversely affects the ability of Heterorhabditis bacteriophora and H.indica to penetrate, infect and reproduce an insect host.

Our results agree with (Hara and Kaya, 1982, 1983; Rovesti et al., 1988; Rovesti and Deseo, 1990; Zhang et al., 1994; Gordon et al., 1996). They generally accepted the mode of action of nematicides which is not the direct killing of the nematodes, but the adverse effects on various aspects of behavior and development. Some of the behavioral effects include inhibition of motility, dispersion, attraction of plant hosts, and attraction of males to females (Greco and Fhomason, 1980; Marban-Mendoza and Viglierchio, 1980 a , b). Direct developmental effects include inhibition of egg production, hatching, and molting (Hough and Thomason, 1975; Marban-Mendoza and Viglierchio, 1980 c). Hara and Kaya (1982) suggest that S. feltiae can be used before the pesticide or the pesticide and nematode applications can be spaced apart to allow for pesticide degradation. Their results showed also some of the effects of organophosphates and carbamates are similar to plantparasitic nematodes. Reduced reproduction, or reproductive failure, may be explained in part by the disruption of the nematode's mating behavior. Lack of juvenile development may be due to the inhibition of molting by the organophosphates and carbanlates. Followed studies by Petersen et al. (1986) showed that fenamiphos was found at detectable levels in turfgrass 
clippings and thatch two months after application and in soil six months after application. Prolonged exposure to this pesticide, however, may reduce the efficiency of the nematodes to infect the insect host or may cause nematode mortality (Kaya and Burlando,1989). Movement of $S$. feltiae was slightly reduced by exposure to deltamethrin (Rovesti and Deseo, 1990) and trichlorfon was found to reduce $S$. carpocapsae infectivity to unacceptable levels (Zhang et al., 1994). Head et al.(2000) reported that a limited range of insecticides can be applied simultaneously with $S$. feltiae, alternatively high levels of control of leafminer larvae can be achieved by the application of $S$. feltiae to vegetable foliage previously treated with insecticides.

\section{REFERENCES}

Anany ,A.E.(2005).Effect of some environmental factors on the activity and vitality of nematode infecting insect pests. Ph.D. Thesis Fac. Agric. AlAzhar Univ. 193 pp

Duncan's, D.B. (1955). Multiple ranged multiple F-test- Biometrics, 11:1- 47.

Elizabeth A. B. De Nardo ; S.Parwinder and Grewal (2003).Compatibility of Steinernema feltiae (Nematoda: Steinernematidae) with pesticides and plant growth regulators used in glasshouse plant production. Biocontrol Science and Technology: 13(4) 441- 448.

Gaugler, R. and J.F. Campbell(1991). Behavioural response of the entomopathogenic nematodes Steinernema carpocapsae and Heterorhabditis bacteriophora to oxamyl. Ann. Appl. Biol. 119: 131138.

Gordon, R. ; J. Chippett, and J. Tilley (1996). Effects of Two Carbamates on Infective Juveniles of Steinernema carpocapsae All Strain and Steinernema feltiae Umefi Strain. J. Nematol. 28(3):310-317.

Greco, N., and I. J. Fhomason (1980). Effect of phenamiphos on Heterodera schachtii and Meloidogyne javanica. J. Nematol. 12:91-96.

Hara, A. H. and H. K. Kaya (1982). Effects of selected insecticides and nematicides on the in vitro development of the entomogenous nematode Neoaplectana carpocapsae.J. Nematol. 14 (4):486-491.

Hara, A. H. and H. K. Kaya (1983). Toxicity of selected organophosphate and carbamate pesticides to infective juveniles of the entomogenous nematode Neoplectana carpocapsae (Rhabditida: Steinernematidae). Environ. Entomol. 12: 496-501.

Head, J.; K.F.A. Walters and S. Langton (2000). The compatibility of the entomopathogenic nematode, Steinernema feltiae, and chemical insecticides for the control of the South American leafminer, Liriomyza huidobrensis. BioControl 45: 345-353, 2000.

Hough, A., and I. J. Thomason. (1975). Effects of aldicarb on the behavior of Heterodera schachtii and Meloidogyne javanica. J. Nematol. 7:221229.

Ishibashi, N. and S. Takii, (1993). Effects of insecticides on movement, nictation, and infectivity of Steinernema carpocapsae. J. Nematol. 25(2): 204-213. 
Kaya, H. K. and T. M. Burlando, (1989). Infectivity of Steinernema feltiae in fenamiphos-treated sand. J. Nematol. 21:434-436.

Marban-Mendoza, N., and D. R. Viglierchio ( 1980a). Behavioral effects of carbofuran and phenamiphos oil Pratylenchus vulnus. I. Motility and dispersion. J. Nematol. 12:102-114.

Marban-Mendoza, N., and D. R. Viglierchio (1980b). Behavioral effects of carbofuran and phenamiphos on Pratylenchus vulnus. II. Attraction to bean roots. J. Nematol. 12:114-118.

Marban-Mendoza, N., and D. R. Viglierchio (1980c). Behavioral effects of carbofuran and phenamiphos on Pratylenchus vulnus. III. Penetration and development. J. Nematol. 12:119-129.

Patel,M.N. and D.J. Wright (1996). The influence of neuroactive pesticides on the behaviour of entomopathogenic nematodes.J. of Helminthology, 70:53-61

Petersen, D., W. Winterlin and L. R. Costello (1986). Nemacur residues in turfgrass. California Agriculture 40 (3 and 4):26-27.

Rovesti, L.and K.V. Deseo (1990).Compatibility of Chemical Pesticides With the Entomopathogenic Nematodes, Steinernema Carpocapsae Weiser and S. Feltiae Filipjev (Nematoda: Steinernematidae). Nematologica, 36(4) 237-245.

Rovesti, L., E.W. Heinzpeter , F.Tagliente , K.V. Deseo (1988) Compatibility of Pesticides With the Entomopathogenic Nematode Heterorhabditis Bacteriophora Poinar (Nematoda: Heterorhabditidae). Nematologica, 3 (4) $462-476$.

Susurluk, A. (2006). Effectiveness of the entomopathogenic nematodes, Heterorhabditis bacteriophora and Steinernema feltiae against Tenebrio molitor (Yellow Mealworm) larvae at different temperature and soil types. Turk J Biol 30, 4: 199-205.

Woodring, J.L. and H.K. Kaya (1988). Steinernematid and Heterorhabditid Nematodes: A Handbook of Techniques Southern Cooperatives. Series Bulletin, Vol. 331, p: 28. Arkansas Experiment Station Fayetteville, AR,USA.

Zhang, L., T. Shono, S. Yamanaka and H. Tanabe(1994). Effects of insecticides on the entomopathogenic nematode Steinernema carpocapsae. Appl. Entomol. and Zool. 29(4): 539-547. 
Anany, A. E. et al.

تأثير بعض المبيدات الحشرية و النيماتودية على إختراق وكفاءة وإنتاج النيمـاتودا

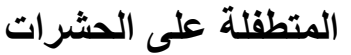

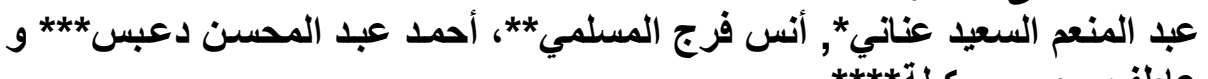

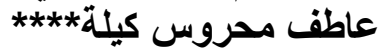

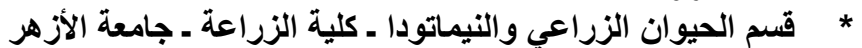

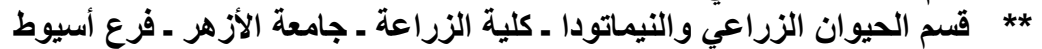

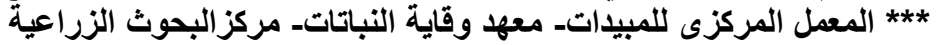

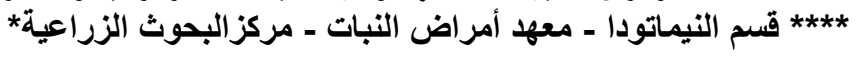

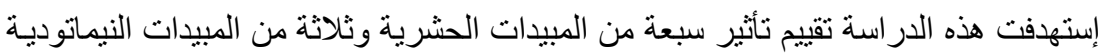

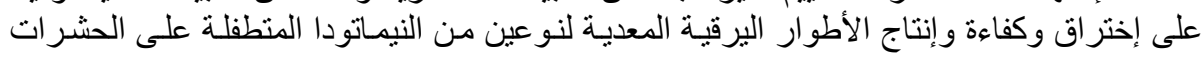

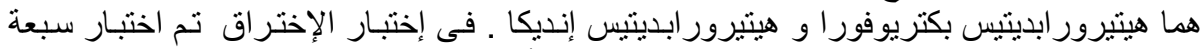

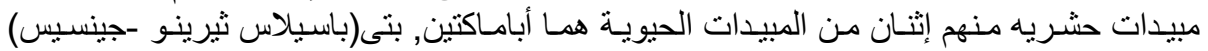

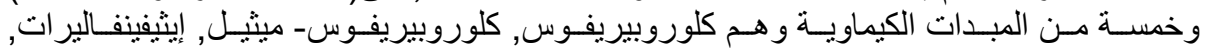

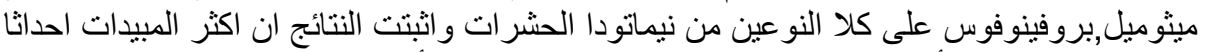

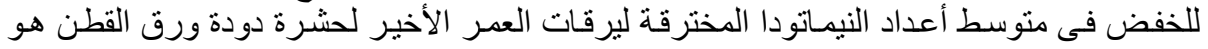

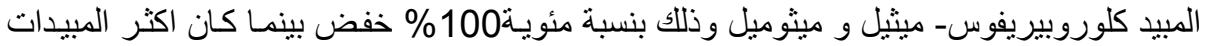

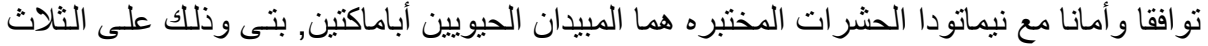
التركيزات المختبرة لكل مبيد.

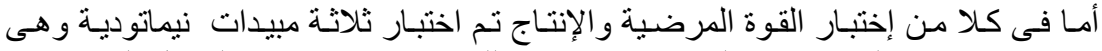

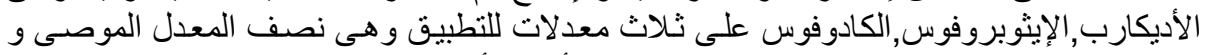

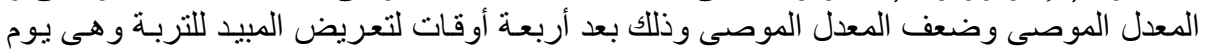

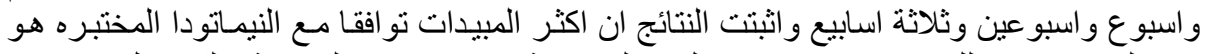

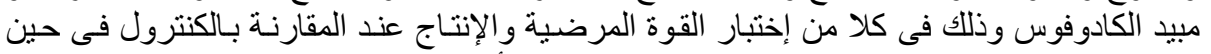

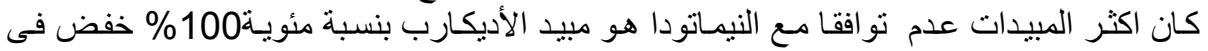

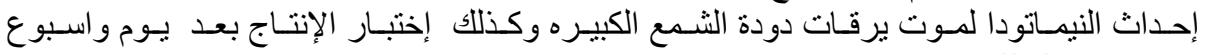
و واسبو عين وثلاثة اسابيع.

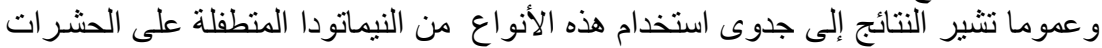

فى نظم المكافحه المتكاملة مع المبيدات المختبرة فى الحماية من الأفات الحشرية.

كلية الزراعة - جامعة المنصورة كلية الزراعة - جامعة الأزهر

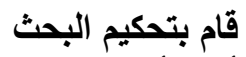

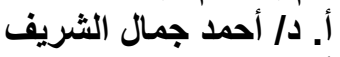
أ. د/ دصطفى عبد اللطيف مصطفى الثريف 
J. of Plant Protection and Pathology, Vol. 1 (4): 219 - 230, 2010

Table (1):Influence of seven insecticides on penetration of Heterorhabdits nematodes last instar Spodoptera littoralis larvae.

\begin{tabular}{|c|c|c|c|c|c|c|c|c|c|c|c|c|c|c|c|c|c|c|c|c|c|c|}
\hline \multirow{4}{*}{$\begin{array}{c}\text { Insecticides } \\
\begin{array}{c}\text { Nematode } \\
\text { species }\end{array}\end{array}$} & \multicolumn{22}{|c|}{${ }^{*}$ Means of Heterorhabditis nematodes penetrated to Spodoptera littoralis larvae } \\
\hline & \multicolumn{3}{|c|}{$\begin{array}{c}\text { Abamactin } \\
1.8 \%\end{array}$} & \multicolumn{3}{|c|}{$\begin{array}{l}\text { B.t. } \\
2 X\end{array}$} & \multicolumn{3}{|c|}{$\begin{array}{c}\text { Chloropyrifos } \\
48 \%\end{array}$} & \multicolumn{3}{|c|}{$\begin{array}{c}\text { Chloropyrifos- } \\
\text { methyl } 50 \%\end{array}$} & \multicolumn{3}{|c|}{$\begin{array}{c}\text { Esfenvalerate } \\
5 \%\end{array}$} & \multicolumn{3}{|c|}{ methomyl $90 \%$} & \multicolumn{3}{|c|}{$\begin{array}{c}\text { Profenfos } \\
72 \%\end{array}$} & \multirow{3}{*}{ 竞 } \\
\hline & 50 & 60 & 80 & 150 & 175 & 200 & 700 & 850 & 1000 & 700 & 850 & 100 & 400 & 500 & 600 & $150 \mathrm{~g} /$ & 200 & 300 & 500 & 600 & 750 & \\
\hline & $\mathrm{ml} / \mathrm{F}$ & $\mathrm{ml} / \mathrm{F}$. & $\mathrm{ml} / \mathrm{F}$ & $g / F$. & g/ F & g/ F. & $\mathrm{ml} / \mathrm{F}$. & $\mathrm{ml} / \mathrm{F}$ & $\mathrm{ml} / \mathrm{F}$ & $\mathrm{ml} / \mathrm{F}$ & $\mathrm{ml} / \mathrm{F}$ & $\mathrm{ml} / \mathrm{F}$ & $\mathrm{ml} / \mathrm{t}$ & $=. \mathrm{ml} / \mathrm{F}$ & $=\mathrm{ml} / \mathrm{t}$ & F. & g/ F. & g/ F. & $\mathrm{ml} / \mathrm{F}$. & $\mathrm{ml} / \mathrm{F}$. & $\mathrm{ml} / \mathrm{F}$. & \\
\hline $\begin{array}{l}\text { Heterorhabditis } \\
\text { bacteriophora }\end{array}$ & 53.7 & 34.0 & 27.3 & 52.7 & 46.7 & 42.0 & 12.0 & 9.0 & 5.0 & 0.00 & 0.00 & $0.0 c$ & 36. & \begin{tabular}{l|l}
3 & 31.3
\end{tabular} & 324. & 0.00 & 0.00 & 0.00 & 29.7 & 17.3 & 10.3 & 59.3 \\
\hline $\begin{array}{l}\text { Heterorhabditis } \\
\text { indica }\end{array}$ & 38.3 & 29.3 & 20.3 & 37.3 & 28.7 & 16.3 & 14.0 & 10.7 & 5.7 & 0.00 & 0.00 & 0.0 & 28. & \begin{tabular}{l|l}
7 & 22.3 \\
\end{tabular} & \begin{tabular}{l|l}
3 & 14. \\
\end{tabular} & \begin{tabular}{l|l|l}
3 & 0.00 & 0
\end{tabular} & 0.00 & 0.00 & 19.3 & 9.7 & 7.3 & 41.3 \\
\hline
\end{tabular}

* Means followed by the same letters within a column are not significantly different $(P \leq 0.05)$ according to Duncan's multiple range test. 
Table (2): Effect of three nematicides on infectivity of Heterorhabditis bacteriophora against Galleria mellonella larvae.

\begin{tabular}{|c|c|c|c|c|c|c|c|c|c|c|c|c|c|}
\hline \multirow[b]{3}{*}{ Rates of application } & \multirow{3}{*}{$\begin{array}{c}\text { Exposure } \\
\text { time }\end{array}$} & \multicolumn{12}{|c|}{${ }^{\star}$ Means of mortality of Galleria mellonella larvae } \\
\hline & & \multicolumn{4}{|c|}{ Aldicarb } & \multicolumn{4}{|c|}{ Ethoprophos } & \multicolumn{4}{|c|}{ Cadusafos } \\
\hline & & Day & Week & \begin{tabular}{|c|} 
Tow \\
weeks
\end{tabular} & $\begin{array}{l}\text { Three } \\
\text { weeks }\end{array}$ & Day & Week & $\begin{array}{c}\text { Tow } \\
\text { weeks }\end{array}$ & $\begin{array}{l}\text { Three } \\
\text { weeks }\end{array}$ & Day & Week & \begin{tabular}{|c|} 
Tow \\
weeks
\end{tabular} & $\begin{array}{l}\text { Three } \\
\text { weeks }\end{array}$ \\
\hline \multirow{4}{*}{ Half recommended } & $24 \mathrm{hr}$. & $0.00 \mathrm{c}$ & $0.00 \mathrm{c}$ & $0.00 \mathrm{c}$ & $0.00 \mathrm{c}$ & $0.00 \mathrm{c}$ & $0.00 \mathrm{c}$ & $0.00 \mathrm{c}$ & $0.00 \mathrm{c}$ & $0.00 \mathrm{~d}$ & $0.00 \mathrm{de}$ & 0.00 ef & $0.00 \mathrm{~d}$ \\
\hline & $48 \mathrm{hr}$. & $0.00 \mathrm{c}$ & $0.00 \mathrm{c}$ & $0.00 \mathrm{c}$ & $0.00 \mathrm{c}$ & $0.00 \mathrm{c}$ & $0.00 \mathrm{c}$ & $0.00 \mathrm{c}$ & $0.33 \mathrm{c}$ & $1.33 \mathrm{bc}$ & $2.66 \mathrm{c}$ & $3.33 \mathrm{c}$ & $4.33 \mathrm{a}$ \\
\hline & $72 \mathrm{hr}$. & $0.00 \mathrm{c}$ & $0.00 \mathrm{c}$ & $0.00 \mathrm{c}$ & $0.00 \mathrm{c}$ & $0.00 \mathrm{c}$ & 0.000 & $0.00 \mathrm{c}$ & $0.33 \mathrm{c}$ & $2 \mathrm{~b}$ & $3.33 \mathrm{bc}$ & $4 \mathrm{bc}$ & $4.66 \mathrm{a}$ \\
\hline & $96 \mathrm{hr}$. & $0.00 \mathrm{c}$ & $0.00 \mathrm{c}$ & $0.00 \mathrm{c}$ & $0.00 \mathrm{c}$ & $0.00 \mathrm{c}$ & $0.00 \mathrm{c}$ & $0.00 \mathrm{c}$ & $0.33 \mathrm{c}$ & $2 \mathrm{~b}$ & $3.33 \mathrm{bc}$ & $4 \mathrm{bc}$ & $4.66 \mathrm{a}$ \\
\hline \multirow{4}{*}{ Recommended rate } & $24 \mathrm{hr}$. & $0.00 \mathrm{c}$ & $0.00 \mathrm{c}$ & $0.00 \mathrm{c}$ & $0.00 \mathrm{c}$ & $0.00 \mathrm{c}$ & 0.000 & $0.00 \mathrm{c}$ & $0.00 \mathrm{c}$ & $0.00 \mathrm{~d}$ & $0.00 \mathrm{de}$ & 0.00 ef & $0.00 \mathrm{~d}$ \\
\hline & $48 \mathrm{hr}$. & $0.00 \mathrm{c}$ & $0.00 \mathrm{c}$ & $0.00 \mathrm{c}$ & $0.00 \mathrm{c}$ & $0.00 \mathrm{c}$ & $0.00 \mathrm{c}$ & $0.00 \mathrm{c}$ & $0.00 \mathrm{c}$ & $0.00 \mathrm{~d}$ & $0.66 \mathrm{de}$ & $1.00 \mathrm{de}$ & $1.33 \mathrm{bc}$ \\
\hline & $72 \mathrm{hr}$. & $0.00 \mathrm{c}$ & $0.00 \mathrm{c}$ & $0.00 \mathrm{c}$ & $0.00 \mathrm{c}$ & $0.00 \mathrm{c}$ & 0.000 & $0.00 \mathrm{c}$ & $0.00 \mathrm{c}$ & $0.33 \mathrm{~d}$ & $1.00 \mathrm{de}$ & $1.33 \mathrm{~d}$ & $1.66 \mathrm{~b}$ \\
\hline & $96 \mathrm{hr}$. & $0.00 \mathrm{c}$ & $0.00 \mathrm{c}$ & $0.00 \mathrm{c}$ & $0.00 \mathrm{c}$ & $0.00 \mathrm{c}$ & $0.00 \mathrm{c}$ & $0.00 \mathrm{c}$ & $0.00 \mathrm{c}$ & $0.66 \mathrm{~cd}$ & $1.33 \mathrm{~d}$ & $1.33 \mathrm{~d}$ & $2.00 \mathrm{~b}$ \\
\hline \multirow{4}{*}{$\begin{array}{l}\text { Double } \\
\text { recommended rate }\end{array}$} & $24 \mathrm{hr}$. & $0.00 \mathrm{c}$ & $0.00 \mathrm{c}$ & $0.00 \mathrm{c}$ & $0.00 \mathrm{c}$ & $0.00 \mathrm{c}$ & $0.00 \mathrm{c}$ & $0.00 \mathrm{c}$ & $0.00 \mathrm{c}$ & $0.00 \mathrm{~d}$ & $0.00 \mathrm{de}$ & 0.00 ef & $0.00 \mathrm{~d}$ \\
\hline & $48 \mathrm{hr}$. & $0.00 \mathrm{c}$ & $0.00 \mathrm{c}$ & $0.00 \mathrm{c}$ & $0.00 \mathrm{c}$ & $0.00 \mathrm{c}$ & $0.00 \mathrm{c}$ & $0.00 \mathrm{c}$ & $0.00 \mathrm{c}$ & $0.00 \mathrm{~d}$ & $0.33 \mathrm{de}$ & $0.33 \mathrm{ef}$ & $0.33 \mathrm{~d}$ \\
\hline & $72 \mathrm{hr}$. & $0.00 \mathrm{c}$ & $0.00 \mathrm{c}$ & $0.00 \mathrm{c}$ & $0.00 \mathrm{c}$ & $0.00 \mathrm{c}$ & $0.00 \mathrm{c}$ & $0.00 \mathrm{c}$ & $0.00 \mathrm{c}$ & $0.00 \mathrm{~d}$ & $0.33 \mathrm{de}$ & $0.33 \mathrm{ef}$ & $0.66 \mathrm{~cd}$ \\
\hline & $96 \mathrm{hr}$. & $0.00 \mathrm{c}$ & $0.00 \mathrm{c}$ & $0.00 \mathrm{c}$ & $0.00 \mathrm{c}$ & $0.00 \mathrm{c}$ & $0.00 \mathrm{c}$ & $0.00 \mathrm{c}$ & $0.00 \mathrm{c}$ & $0.00 \mathrm{~d}$ & $0.33 \mathrm{de}$ & $0.33 \mathrm{ef}$ & $0.66 \mathrm{~cd}$ \\
\hline \multirow[b]{4}{*}{ Control } & $24 \mathrm{hr}$. & $0.33 \mathrm{c}$ & $0.33 \mathrm{c}$ & $0.33 \mathrm{c}$ & $0.33 \mathrm{c}$ & $0.33 \mathrm{c}$ & $0.33 \mathrm{c}$ & $0.33 \mathrm{c}$ & $0.33 \mathrm{c}$ & $0.33 \mathrm{c}$ & $0.33 \mathrm{c}$ & $0.33 \mathrm{c}$ & $0.33 \mathrm{c}$ \\
\hline & $48 \mathrm{hr}$. & $4.33 \mathrm{~b}$ & $4.33 \mathrm{~b}$ & $4.33 \mathrm{~b}$ & $4.33 \mathrm{~b}$ & $4.33 \mathrm{~b}$ & $4.33 \mathrm{~b}$ & $4.33 \mathrm{~b}$ & $4.33 \mathrm{~b}$ & $4.33 \mathrm{a}$ & $4.33 \mathrm{ab}$ & $4.33 \mathrm{a}$ & $4.33 \mathrm{a}$ \\
\hline & $72 \mathrm{hr}$. & $5.00 \mathrm{a}$ & $5.00 \mathrm{a}$ & $5.00 \mathrm{a}$ & $5.00 \mathrm{a}$ & $5.00 \mathrm{a}$ & $5.00 \mathrm{a}$ & $5.00 \mathrm{a}$ & $5.00 \mathrm{a}$ & $5.00 \mathrm{a}$ & $5.00 \mathrm{a}$ & $5.00 \mathrm{a}$ & $5.00 \mathrm{a}$ \\
\hline & $96 \mathrm{hr}$. & $5.00 \mathrm{a}$ & $5.00 \mathrm{a}$ & $5.00 \mathrm{a}$ & $5.00 \mathrm{a}$ & $5.00 \mathrm{a}$ & $5.00 a$ & $5.00 \mathrm{a}$ & $5.00 \mathrm{a}$ & $5.00 \mathrm{a}$ & $5.00 \mathrm{a}$ & $5.00 \mathrm{a}$ & $5.00 \mathrm{a}$ \\
\hline
\end{tabular}

${ }^{*}$ Means followed by the same letters within a column are not significantly different $(P \leq 0.05)$ according to Duncan's multiple range test. 
J. of Plant Protection and Pathology, Vol. 1 (4), April, 2010 